\title{
Impact of the COVID-19 Pandemic on Changing the Content of Social Media Advertising
}

\section{Wpływ pandemii COVID-19 na zmianę treści reklam w mediach społecznościowych}

\author{
Andrea Seberíni ${ }^{1}$, Miroslava Tokovska ${ }^{2}$ \\ ${ }^{1}$ Faculty of Economics, Matej Bel University, Slovakia \\ ${ }^{2}$ School of Health Sciences, Kristiania University College, Oslo, Norway \\ ORCID AS https://orcid.org/0000-0002-8531-1611; MT https://orcid.org/0000-0002-8279-3168 • andrea.seberini@umb.sk \\ Received: 30 June, 2021; Revised: 03 Aug, 2021; Accepted: 10 Aug, 2021
}

\begin{abstract}
Social media and advertising offers opportunities for receiving pre- and post-purchase information. Advertising plays a significant role in business marketing, as every company wants its product to be successful, and familiar to its target audience, and thus, it is essential to promote it. Promotion plays an important role within the marketing mix, as its aim is to draw the attention of potential buyers. The main purpose of this study is to find out how social media, especially advertising, changed its content during the COVID-19 pandemic. A questionnaire was distributed among respondents by means of social media. This way we included representatives of each age category trying to resemble, as closely as possible, the Slovak market. From among the randomly selected participants (social media users), 135 respondents completed the questionnaire. As for the impact of the COVID-19 pandemic, in terms of advertising, we found out that there had been a certain change. According to the answers of our respondents, the changes related to the content of advertisements, the motives used, their narratives, offered products or services, or the combination of all the above. Consumers noticed an increased amount of COVID-19 related products such as face masks, disinfectants, etc.
\end{abstract}

Keywords: COVID-19, social media, advertising, internet, digital advertising

Streszczenie: Media społecznościowe i reklamy oferują możliwość otrzymywania informacji przed i po zakupie. Reklama odgrywa znaczącą rolę w marketingu, ponieważ każda firma dąży do tego, aby jej produkt odniósł sukces i był rozpoznawalny wśród docelowych odbiorców, dlatego właściwa promocja produktu jest bardzo ważna. Promocja odgrywa istotną rolę w kompozycji marketingowej, ponieważ jej zadaniem jest przyciąganie uwagi potencjalnych nabywców. Głównym celem niniejszego opracowania jest ustalenie, w jaki sposób media społecznościowe, a zwłaszcza reklama, zmieniły swój przekaz podczas pandemii COVID-19. Ankieta została rozesłana wśród respondentów za pośrednictwem mediów społecznościowych. Staraliśmy się uwzględnić reprezentantów każdej grupy wiekowej tak, aby jak najpełniej odwzorować rynek słowacki. Spośród wybranych losowo uczestników (użytkowników mediów społecznościowych), ankietę wypełniło 135 respondentów. Skutki pandemii COVID-19 w zakresie reklamy spowodowały pewne zmiany. Według odpowiedzi respondentów zmiany te dotyczyły treści reklam, zastosowanych motywów, ich narracji, oferowanych produktów, usług lub wszystkich wymienionych elementów łącznie. Konsumenci zauważyli zwiększoną ilość produktów związanych z COVID-19, szczególnie takich, jak maseczki ochronne, środki dezynfekcyjne itp.

Słowa kluczowe: COVID-19, media społecznościowe, reklama, Internet, reklama cyfrowa 


\section{Introduction}

In an age of rapidly evolving technology and the significant availability of information, it cannot be denied that the world we live in is rapidly changing. The growth of social media has changed the way we communicate. The number of social media users worldwide was estimated to be 3.6 billion in 2020 (Statista 2021). The rapid pace of development of science, globalisation, the transition to an information society and digital economy, have contributed to a significant transformation of potential consumers and their behaviour (Galková et al. 2019). According to Chopra and Gupta (2020), the internet and advertising is part of the everyday lives of the world's population, affecting a new form of communication through social networking sites. Social media and advertising offer opportunities for receiving pre- and post-purchase information. Availability of the internet has provided individuals with the opportunity to use social networks, such as Twitter and Facebook, to interact without the need for physical meetings.

Through social media and advertising, companies can increase brand awareness, positive word-of-mouth, sales, and generate greater support. Social media platforms have enabled a two-way flow of information that allows companies to influence the purchasing decisions of targeted groups. Past research suggests that particularly passive interactions with social media content can trigger social comparisons (Orben 2020). The influence and comparisons brought on by social media content is troubling, considering that some trends convey unrealistic beauty ideals, arising from manipulated images, cosmetic surgery, and an extreme fitness focus. This kind of comparison increases the distance between one's self-image and an unattainable ideal, which in turn, can have a negative impact on one's body image (Kleemans et al. 2018). Each blog entry, picture, video, or remark may lead watchers to your organisation's site and increment traffic. The web, which is based on social networking advertising, allows businesses to make a positive impression through an adaptation factor (Chopra and Gupta 2020).

The main aim of the study is to find out how social media, especially advertising, has changed its content during the pandemic COVID-19.

Social media is an integral part of modern society and is gradually becoming an important marketing tool that provides companies with ample opportunities to interact with their consumers. Today, social media is considered an important cultural phenomenon all over the world. Therefore, the number of active users of social media is growing significantly every year. In 2020, the number of social media users increased by $10.5 \%$ in the world, compared to the previous year, and amounted to 3.96 billion people $(51.1 \%$ of the world's population). Which means that $86.6 \%$ of the population is connected to the Internet (Statista 2021).

The good image of brands or products can lead the consumer to make decisions on their purchases. When a consumer's friend on social media, shares or recommends services or products on their social media, it may affect brand attitudes and influence their decision-making. Practice shows that social media is an essential part of the marketing and communication strategies of many medical organisations. Any brand that has a good image on social media gets higher benefits, and consumers prefer that brand. Marketers sometimes get involved in compiling negative publicity for competitors' brands to decrease their market value and attract customers towards themselves. The research was conducted in a form of a semi-structured anonymous on-line questionnaire through the Google forms platform. Semi-structured questionnaire aims to reach both qualitative and quantitative output and thus, includes a mix of both closed and open questions. (B2B International 2021) The questionnaire was distributed among respondents by using social media. This way we tried to have representatives of each age category trying 
to resemble as closely as possible the Slovak market. Following the random selection of participants who were addressed 135 filled in the questionnaire

\section{Advertising and social media}

The roots of advertising date back to ancient times, making it a very old kind of promotion. However, during the past decades, the means and practices have changed, mainly due to emerging new technology. This eventually leads to a decline of traditional advertising, when people start to prefer digital sources over, for example, the printed text or television. According to the On-line Etymology Dictionary, the verb 'advertise' has its roots in the Latin word advertere - ad meaning 'to' or 'towards', and vertere 'to turn', therefore, literally meaning 'to turn towards' (Etymonline 2012).

Advertising is one of the forms of marketing communication mostly used for commercial purposes, with the aim to reach out to and influence a wide range of the public, through the use of different means and techniques, eventually leading to sales boosts or customer acquisition. Advertising, as part of the promotional strategy, needs to deliver a message to the target market that will lead to a favourable reaction. Its main aim is to motivate the audience to take the 'next step of action.' (University of Pretoria, n.d.)

Social media is used daily for several hours a day. Every day, a lot of new accounts are being set up in the world, and the Internet, as such, is gradually entering the once remote parts of the world. The way we communicate, search for information, reserve systems, influences the financial markets themselves, while all aspects of our lives are influenced by this new phenomenon - social media. Along with advertising, social media refer to promotion via platforms, such as Facebook, Instagram, Google+ and many more. According to the Global Digital Report: out of a total population of over 7.5 billion people in the world, more than 4 billion people have access to the internet, and more than 3.1 billion were active on social networks in 2018 , representing $42 \%$ of the total world population. In the case of a detailed analysis by country and region, more than $88 \%$ of Americans, $90 \%$ of Western Europeans, and 94\% of Northern Europeans have access to the internet. It is also possible to observe a year-on-year increase in the number of social media users on a global average of $13 \%$. In countries such as Saudi Arabia and India, it is even year-on-year increase in the number of users by more than $30 \%$, and in China, this figure exceeded 20\% (Statista.com 2021). With the largest number of daily users, Facebook is the most widespread on-line platform in the world. Facebook has an average impact of more than $10 \%$ and $26.8 \%$, respectively, than other social media. Facebook is a good platform for organic and paid opportunities for many companies. With over 2.2 billion users, Facebook is also the most visited social media site in the world, followed by YouTube, WhatsApp, Facebook Messenger and more. It is also worth mentioning that both WhatsApp and Messenger belong to the Facebook Group. Twitter, with its 335 million users, ranks 11th in terms of number of users, based on the Statistics Analysis, which used data from the Global Web Index (Statista.com 2021).

When advertising through social media, it is important to choose the platform wisely according to the target group, because each platform is different, and their audiences are likely to differ as well. "In comparison with traditional mass media advertising or on-line ads, firms are able to have more informative and interactive communication with their customers" (Alalwan 2018). Additionally, the impact can be measured immediately, as everything on social media happens in 'real time'. Another type is $\mathrm{Na-}$ tive advertising, which "involves presenting on-line content consumers with advertisements that resemble, in format and content, the non-advertising content that is published on the same platform" (Wojdynski $2016,2)$. Since they are created in a manner that matches the overall message, the user 
does not feel that he/she is in fact, engaging with an ad. Finally, there is display advertising, whereby a display ad is usually embedded at the top or the sides of web pages. "Display advertisements are extremely prevalent on-line, which can damage their effectiveness, because they provide no value to consumers other than a call-to-action, so users have learned to ignore display ads and click-through rates fall" (Goorevich 2019).

\section{Types of advertising}

There are a lot of ways in which the product or the brand can be advertised. The company, whilst planning an advertising campaign should define their target audience, and consequently, choose an adequate type of advertising to make their targets as engaged as possible. Goorevich (2019) divides the types of advertising into two bigger categories, which are traditional and digital advertising. These are then further divided into more sub-categories.

According to Goorevich's division (2019), the first type of Advertising is Traditional Advertising, which refers to advertising through mass media. It uses typical channels such as television, radio, billboards, and many others. These can reach out to a huge audience, but on the other hand, it is hard to evaluate whether the target audience was reached. One example of the traditional types of advertising is Print advertising, which uses physically printed media to reach potential customers. This includes newspapers, brochures, leaflets, magazines, or even direct mail (letters, postcards) and posters (Goorevich 2019). After that, there is Broadcast advertising. This refers to sharing a message via the media of radio or television. Broadcasting, however, serves more as an attention drawer, rather than a direct link to sales. Moreover, these are currently in decline as the traditional TV and radio media forms are losing their spectators to new substitutes like Netflix and Spotify. Another type of traditional advertising is Outdoor advertising, also known as out-of-home $(\mathrm{OOH})$ advertising. The aim is to target potential customers anywhere outside their home. Nowadays, outdoor advertising is often connected with digital advertising, for example, by the use of QR codes or other means (Broadsign 2018).

The second type is Digital Advertising. We will focus on several types of Digital Advertising, as divided by Goorevich (2019). For advertisers, Digital Advertising also provides immediate feedback about interactions and engagement. This means information about who has engaged with the advertisement, how that person engaged, and whether or not it led to a sale (Goorevich 2019). Sub-groups of Digital Advertising are described below. Firstly, there is Paid Search advertising. This allows companies to show their ads on search engines. Ads are usually connected with specific keywords, and once they are searched, the browser shows an ad on the top of their search engine results page (SERP) (Goorevich 2019). Secondly, there is Social Media advertising. This refers to promotion via social media platforms, such as Facebook, Instagram, Google+, and many more. When advertising through social media, it is important to choose the platform wisely, according to the target group, because each platform is different, and their audiences are likely to differ as well. "In comparison with traditional mass media advertising or on-line ads, firms are able to have more informative and interactive (twoway) communication with their customers" (Alalwan 2018, 2). Additionally, the impact can be measured immediately, as everything on social media happens in real-time.

Another type is Native advertising. Native advertising "involves presenting on-line content consumers with advertisements that resemble, in format and content, the non-advertising content that is published on the same platform" (Wojdynski $2016,2)$. Since they are created in a manner that matches the overall message, the user is not feeling that he/she is, in fact, engaging with an ad. Finally, there is Display advertising. A display ad is usually embedded at the top or the sides of web pages. "Display 
advertisements are extremely prevalent online, which can damage their effectiveness.

\section{Advertising during the COVID-19 pandemic}

On the $11^{\text {th }}$ of March, 2020, after several months of unsuccessfully battling against COVID-19, a disease caused by the SARSCoV-2 coronavirus, the World Health Organisation declared a global coronavirus pandemic. By that time, the virus, which originated in the Chinese city of Wuhan, had already spread into 114 countries, and killed 4,291 people since December 2019. It became the first pandemic caused by a coronavirus in human history (WHO 2020). The virus spreads by close contact between two people. Therefore, it is recommended to practice social distancing. Due to the coronavirus severity, most countries have opted for lockdowns and travel restrictions for months, so that people stayed safe at home. If someone develops the symptoms, he/she is advised to remain in isolation for the good of others (Muzzafar 2020). This case leads to panic, and people want to be more and more aware of the situation in this crisis. In such circumstances, social media is playing a vital role. Therefore, in this COVID-19 pandemic, this study is trying to analyse the impact of social media on changing the content of advertising and gather knowledge about how advertising affects consumers. At the same time, the work tries to find out the opinion of the general public in Slovakia (users of social media), operating in this pandemic situation.

The changes regarding advertising can be seen, both in the type of advertising, currently used, and its content. As Jordan (2021) explained, out of necessity, businesses quickly moved not just their workforces, but their services and more of their advertising on-line. Bloom (2020) then elaborates on this statement: "using digital and social media to get information out there, especially to the younger generation, was already a trend before the pandemic. This situation has just exacerbated that trend".
As per the content of advertising during the COVID-19 pandemic, Schwab (2020) stated that: "In the absence of economic activity, advertising content has had to be adapted. The brands that continued to advertise, therefore, re-oriented their messages to give them meaning in a particular context". Schwab, later, identifies 5 new trends in advertising messages that arose during the COVID-19 pandemic: 1. saying "thank you" to the company's employees 2. saying "thank you" to the customers 3. saying "thank you" to the nursing staff 4 . showing concerns for the health of customers and employees 5. adaptation of the messages of the previous campaigns (Schwab 2020). Schwab warns that the crisis could also lead to a revision of advertising messages by companies. The changes in consumer expectations, such as the need for re-insurance might lead to an increased focus on motives, such as the family and the home (Schwab 2020).

\section{Methodology and data collection}

The findings reported in this study were drawn from data collected from a survey exploring the behavioural analysis of the impact of social media and advertising, and on behaviour during the COVID-19 pandemic. In this study, an electronic questionnaire was used as the main method of data collection. The university research ethics committee approved this study. The questionnaire as a research tool is very beneficial, as it offers to reach a wide audience, not only local, in a short amount of time, as the answers are received very quickly. Furthermore, as the questionnaire is anonymous, responses tend to be more truthful (Fox et al. 2003). In addition, we conducted a survey using a self-administered method. Such an approach has led to the fact that the method of self-administration in collecting data, directly from respondents is simple, relatively fast, and inexpensive (Saunders et al. 2019). In this research, two different methods are used to select a research sample improbability selection, namely, the 'snowball technique', and the method of self-selection. In 
the snowball method, the research was conducted in a form of a semi-structured, anonymous, on-line questionnaire through the Google forms platform. A semi-structured questionnaire aims to reach both qualitative and quantitative output, and thus, includes a mix of both closed and open questions. The questionnaire was distributed among respondents, by using social media. This way we tried to have representatives of each age category trying to resemble, as closely as possible, the Slovak market. Following the random selection of participants (users of social media) who were addressed, 135 filled in the questionnaire. This research was carried out with Veselá (2021). The data collection took place in the week from the $1^{\text {st }}$ of March till the end of April, 2021.

\section{Data analyses}

Answers of all of the 135 respondents were taken into account. After the data collection, we moved to data processing, using Microsoft Excel. When processing the data, a combination of mathematical and statistical methods was used. Results were then, subsequently, put into figures, to be portrayed in the most comprehensible way possible. The survey was conducted in the Slovak language, in order to obtain more respondents, and break down the possible language barriers that might have arisen due to age, occupation, or education level diversity. The questions and answers were then translated into English for the purposes of this research.

From the provided answers, we found out that from the total number of 135 respondents, 110 were women, representing $81.5 \%$ and 25 were men, representing the other $18.5 \%$ from the whole sample. As the figure 1 shows, all respondents were assigned to 5 age groups.

Based on the data in the table 1, we can see what were the representative percentage figures of particular genders in each age category.

In this research with Veselá (2021), we found out that the highest number of participants, not only among women, but from

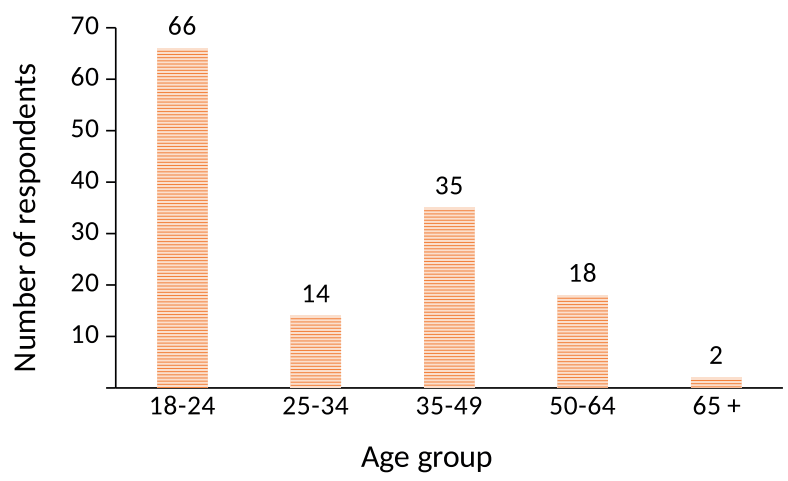

Figure 1. Age of participants (users of social media)

Table 1. Gender representation (in \%) within age groups. N=135

\begin{tabular}{lcc}
\hline Age group (years) & \multicolumn{2}{c}{ Gender } \\
\cline { 2 - 3 } & Male & Female \\
\hline $18-24$ & 8.89 & 40 \\
\hline $25-34$ & 0.74 & 9.63 \\
\hline $35-49$ & 5.93 & 20 \\
\hline $50-64$ & 1.48 & 11.85 \\
\hline $65+$ & 1.48 & - \\
\hline
\end{tabular}


the whole sample, were female participants in the age group of 18-24 years old, being $40 \%$ (54) of the whole sample. Female participants then represented $9.63 \%$ (13) in the age group from $25-34$ years old, $20 \%$ in the age group of people between 35-49 years old, and $11.85 \%$ (16) in the age group of 50-64 years of age. Finally, we did not have any female representative for the category of people over 65 years of age. We were then interested in finding out the highest level of education reached by our participants. From all 135 participants, 8.9\% (12) had completed Elementary education, 42.2\% (57) of respondents marked high school with a leaving certificate as their highest education level reached, 4.4\% (6) stated that they completed high school without a leaving certificate, and finally, the majority $4.4 .4 \%$ (6o) of our respondents were university graduates.

Consumers are increasingly relying on social media to make purchases. According to a recent study, a quarter of all consumers came across new products and services through the content of social media ads. As we can see from the figure 2 , the percentage of consumers most often using social media to watch ads on social networks is Facebook and Instagram. As the figure shows, younger generations tend to use and search for products in social media ads more often than older ones.
Following the numbers in the figure 3, almost half of the respondents $(48.9 \%(66))$ noticed the difference in the contents of advertising during the pandemic, specifically, that the ads these days are aimed mostly at pandemic-related products, such as masks, disinfectants, or protective equipment. $20.7 \%$ (28) noticed the change in narrative or motives used in advertisements, when comparing current adverts with the pre-pandemic ones. From the opposite spectrum, $21.5 \%$ (29) respondents stated that they hadn't noticed any differences and therefore, that the advertisements hadn't changed during the pandemic. There were also 12 (8.9\%) answers under the option "Other". These included various answers, some of them more or less the same. Four people stated that they hadn't been watching ads before the pandemic, and nor were they watching them during the pandemic, so they couldn't tell whether there was a difference or not. Three respondents answered that they had noticed more ads for drugs and vitamins from the beginning of the pandemic. Another 2 stated that the current ads corresponded with current topics. Two then noticed an increase in advertisements for on-line services, and one answer stated that they had spotted the adverts for products, that didn't have to be promoted before the pandemic. If we sum up these results, we can see, that the majority of respondents noticed some

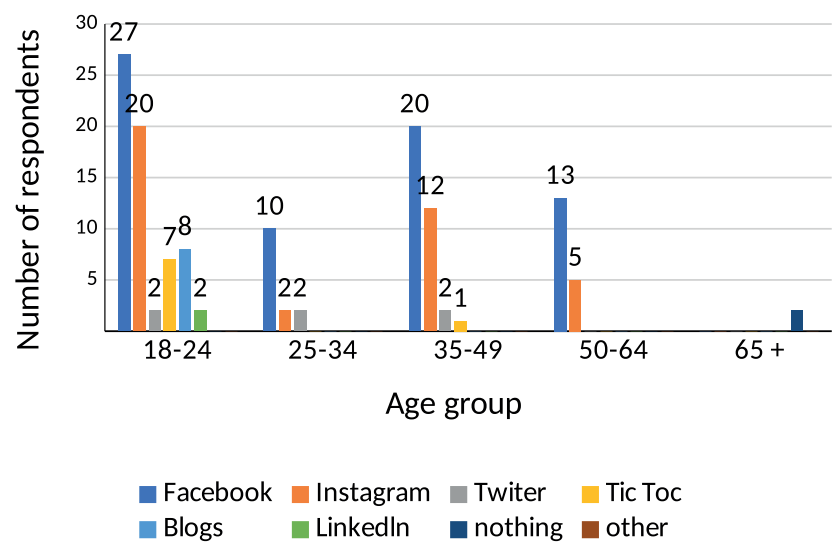

Figure 2. The most common use of social media to watch ads during the pandemic COVID-19 


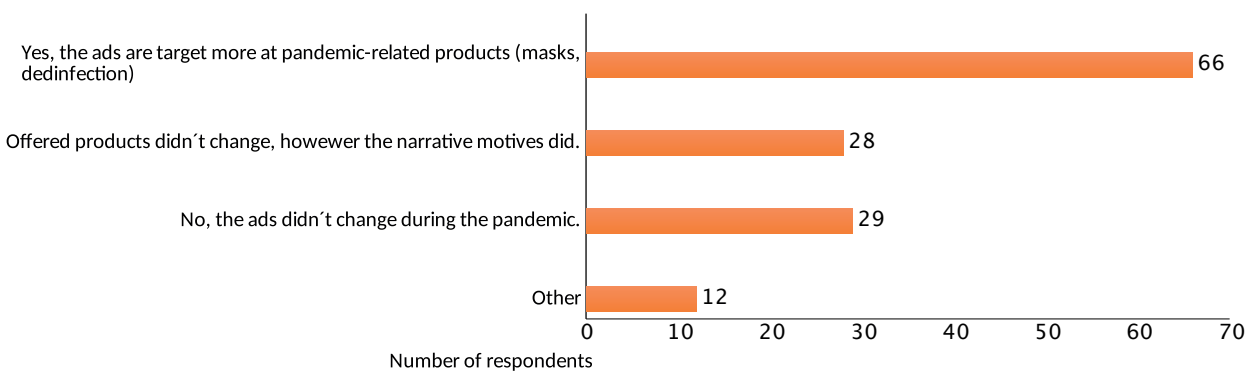

Figure 3. Opinions on the ads content on social media during the COVID-19 pandemic

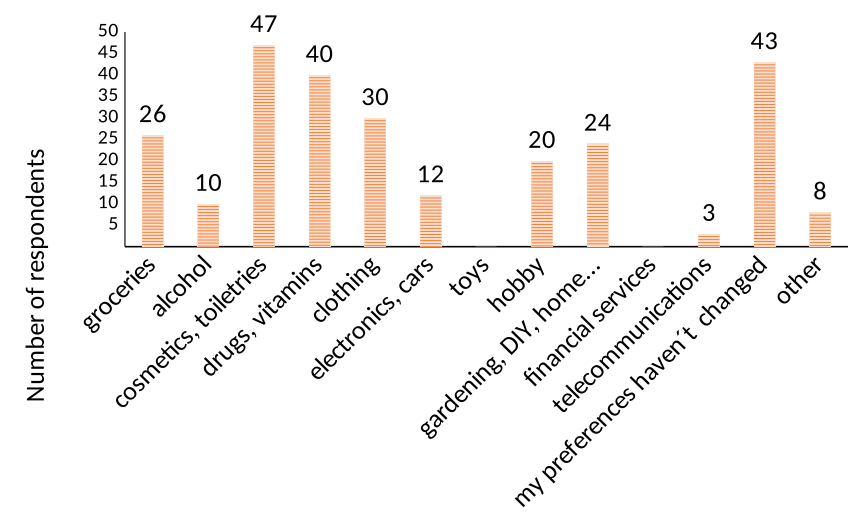

Figure 4. Purchase of content-inspired products on social media during the COVID-19 pandemic

change in advertising during the pandemic, in comparison with pre-pandemic advertising. This was either in its content, offered products and services, narrative, or motives used. As we tackled the subject of consumer behaviour during the COVID-19 pandemic, we also wanted to find out how or if the product preferences of our participants (users of social media) have changed. Whether some products have become more interesting to them, or the pandemic has not affected their product interests at all, or whether it has changed their needs or wants. We offered 12 possible answers, 11 were specific group categories, and the twelfth was, again, option "Other". Respondents were free to choose multiple answers.

Based on the figure 4 , we can see that the attention of our respondents shifted during the COVID-19 pandemic, mostly towards cosmetics and toiletries, as selected by
$34.8 \%$ (47) participants. These were followed closely, by drugs and vitamins, as selected by $29.6 \%$ (40). It can be said that these were the types of products that were expected to become more interesting for consumers, given the nature of the pandemic and the effect it was having on the health of individuals. Considering this, people became likely to try to boost their immune systems, to try to avoid being infected, or to have less severe symptoms. Another commonly selected answer was "clothing" chosen by $\mathbf{2 2 . 2} \%$ of respondents. Then, it was groceries, selected by $19.3 \%$ (26) followed by the category of gardening, DIY, and home improvement that was selected by $17.8 \%$ (24) of respondents. People also became more interested in hobby-related products $(14.8 \%$ (20)), electronics and cars $(8.9 \%(12))$, and alcohol (7.4\% (10)). Telecommunications became more interesting to only $2.2 \%$ (3), while 
categories "toys" and "financial services" were not selected by anyone. There were also 8 answers under the "Other" option, however, all of them answered "no product". On the other hand, 31.9\% (43) of respondents answered that their product preferences remained unchanged throughout the pandemic, and there is no product or product category that would be more appealing or interesting for them now. To sum up this question, the product preferences of almost one-third of the whole sample, remained unchanged. Moreover, if we count people who answered that no product became more interesting to them, the amount will increase to 51 people (37.8\%). For the rest of the sample, those were mainly COVID-19-related products, from the categories of cosmetics and toiletries, together with pharmaceutical products (Veselá 2021).

\section{Conclusion}

Impacts of the COVID-19 pandemic, in terms of advertising, reflected a certain change. According to the answers of our respondents, the changes have been present in either content of advertisements, the motives used, their narrative, offered products or services, or the combination of all mentioned before. Through questions related to the COVID-19 pandemic, we found out that consumers noticed the changes in adverts, either in their content, narrative, or motives used. Consumers noticed an increased amount of COVID-19 related products, such as face masks, disinfectants, protective equipment, etc. As per the product preferences, for more than one-third of our respondents, these remained unchanged. On the other hand, for respondents, whose product preferences have changed during the pandemic, the most common product categories were cosmetics and toiletries, together with pharmaceutical products.

However, it is important to mention that the perception of advertising and consumer behaviour, as well as the content, are highly subjective, thus, given the limitations of our sample, the results of this research might not be relevant for a different group of respondents.

Author Contributions: Conceptualization, A.S. and M.T.; Methodology, M.T.; Validation, A.S. and M.T.; Formal Analysis, A.S. and M.T.; Investigation, A.S.; Writing - Original Draft Preparation, A.S. and M.T.; Writing - Review \& Editing, A.S. and M.T.; Visualization, A.S.; Supervision, M.T. Both authors have read and agreed to the published version of the manuscript.

Funding: This research received no external funding. Institutional Review Board Statement: Not applicable.

Conflicts of Interest: The authors declare no conflict of interest.

\section{References}

Alalwan, Ali. 2018. "Investigating the impact of social media advertising features on customer purchase intention." International Journal of Information Management 42: 65-77. https://doi.org/10.1016/j. ijinfomgt.2018.06.001.

Belch, George, and Michael A. Belch. 2004. Advertising and Promotion. An Integrated Marketing Communications Perspective. New York: McGraw Hill Higher Education.

Bloom, Jonty. 2020. "Coronavirus: How the advertising industry is changing." Accessed June 30, 2021. https://www.bbc.com/news/ business-52806115.

Broadsign. 2018. Everything you need to know about out-of-home advertising. Accessed June 30, 2021. https://broadsign.com/blog/ out-of-home-advertising/.

B2B International. 2021. What Is a SemiStructured Market Research Survey? Accessed June_30,_2021:_https://www.b2binternational. com/resea rch/methods/faq/what-is - asemistructured-market-research-survey/.

Chopra, Chahat, and Sachin Gupta. 2020. "Impact of Social Media on Consumer Behaviour." International Journal of Creative Research Thoughts 8(6): 1943-1961. https://doi.org/10.13140/ RG.2.2.26927.15527.

Cinelli, Matteo, Walter Quattrociocchi, Alessandro Galeazzi, Carlo M. Valensise, Emanuele Brugnoli, Ana L. Schmidt, Paola Zola, Fabiana Zollo, and Antonio Scala. 2020. “The COVID-19 Social Media 
Infodemic." Scientific Reports 10(1): 16598. https:// doi.org/10.1038/s41598-020-73510-5.

Etymonline.com. 2012. Advertise. Accessed June 30, 2021. https://www.etymonline.com/ word/advert?ref=etymonline_crossreference \#etymonline_v_40677.

Fox, Jezz, Craig Murray, and Anna Warm. 2003. "Conducting research using web-based questionnaires: Practical, methodological, and ethical consideration." International Journal of Social Research Methodology 6(2): 167-180. https://doi.org/10.1080/13645570210142883.

Galková, L., Kurčíková, K., Šolcová, J. 2019. Game about Planet. Global education. Banská Bystrica: Belianum, Matej Bel University Press.

Goorevich, Emily. 2019. 7 Types of Advertising (+How They're Used). Accessed June 30, 2021. https://www. g2.com/articles/types-of-advertising.

Gowan, Rob. 2020. "WES for Youth Online sees surge in counselling service use." The Sun Times, April 15, 2020. https://www.owensoundsuntimes. com/news/local-news/wes-for-youth-online-seessurge-in-counselling-service-use.

Hayes, Adam. 2020. Rational Behaviour Definition. Accessed June 30, 2021. https://www.investopedia. com/terms/r/rational-behavior.asp.

Hesham, Fazel, Harizi Riadh, and Nasr K. Sihem. 2021. "What Have We Learned about the Effects of the COVID-19 Pandemic on Consumer Behaviour?" Sustainability 13(8): 4304. https:// doi.org/10.3390/su13084304.

Jordan, Heather. 2021. "Covid-19 Changed The Advertising Playbook. Now What?" Accessed June 30, 2021. https://www.nielsen.com/us/en/ insights/article/2021/covid-19-changed-theadvertising-playbook-now-what/.

Kleemans, M., Daalmans, S., Carbaat, I., \& Anschütz, D. (2018). Picture perfect: The direct effect of manipulated instagram photos on body image in adolescent girls. Media Psychology 21(1): 93-110.

Lamb, Charles W., Joseph F. Hair, and Carl D. McDaniel. 2003. Marketing. Princeton, N.J.: Recording for the Blind \& Dyslexic.

Muzaffar, Aneela. 2020, "COVID-19 pandemic and social media: The Swedish case" Halmstad University. Accessed June 30, 2020. https:// www.diva-portal.org/smash/get/diva2:1440930/ FULLTEXT02.pdf.
Oke, Adunola O., Parinda Kamolshotrios, Oluwamayowa Y. Popoola, Musibau A. Ajagbe, and Olusola J. Olujobi. 2016. "Consumer Behaviour towards Decision Making and Loyalty to Particular Brands. International Review of Management and Marketing 6(4): 43-52.

Okwodu, Janelle. 2020. „Model and Author Naomi Shimada on How to Navigate Social Media in a Time of Crisis." Accessed June 30, 2021. https://www.vogue.com/article/ naomi-shimada-mixed-feelings-social-media interview?utm_source=headtopics\&utm medium=news\&utm_campaign=2020-03-26.

Orben, A. (2020). “Teenagers, screens and social media: a narrative review of reviews and key studies." Social Psychiatry and Psychiatric Epidemiology 55: 407-414.

Pärson, Gustav, and Alexandra Vancic. 2020. "Changed Buying Behaviour in the COVID-19 pandemic - The influence of Price Sensitivity and Perceived Quality." Master thesis, Kristianstad University Sweden, 2020. Accessed June 30, 2021. https://www.diva-portal.org/smash/get/ diva2:1453326/FULLTEXT01.pdf.

Pospisil, Jan. 2010. "Irrationality in consumer behaviour and its influence over the advertising messages." In Proceedings of the 18th Annual Conference on Marketing and Business Strategies for Central \& Eastern Europe: December 2 - 4, 2010 Vienna, Austria, edited by Reiner Springer, 374-378. Vienna: University of Economics and Business.

Rani, Pinki. 2014. "Factors influencing consumer behaviour." International Journal of Current Research and Academic Review 2(9): 52-61. Accessed June 30, 2021. http://www.ijcrar.com/ vol-2-9/Pinki\%20Rani.pdf.

Samat, Muhammad F. 2019. "Promotional Mix." https://doi.org/10.13140/RG.2.2.20165.29920.

Saunders, Mark N., Philip Lewis, and Adrian Thornhill. 2019. Understanding research philosophy and approaches to theory development. In Research Methods for Business Students, edited by Mark N. Saunders, Philip Lewis, and Adrian Thornhill, 128-170. Boston: Pearson.

Schwab, Pierre-Nichals. 2020. "COVID-19: 9 specific impacts on the advertising industry and its future." Accessed June 30, 2021. https://www.intotheminds. com/blog/en/covid-impact-advertising-industry/. 
Statista.com. 2021. Social Media E User-Generated Content. Accessed June 30, 2021. https:// www.statista.com/markets/424/topic/540/ social-media-user-generated-content/\#overview. Twin, Alexandra. 2021. The 4 Ps. Accessed June 30, 2021. https://www.investopedia.com/terms/f/ four-ps.asp.

UNC TV Science. 2018. "How Many Daily Decisions Do We Make?” Accessed June 30, 2021. http:// science.unctv.org/content/reportersblog/choices.

University of Pretoria. n.d. Chapter 2: "Promotional mix." Accessed June 30, 2021 https:// repository. up.ac.za/bitstream/handle/2263/25084/ 02chapter2.pdf? sequence $=3 \&$ isAllowed $=y$.

Veselá, Radka. 2021. "Behavioural analysis of the impact of advertising on the behaviour of market participants." Bachelor thesis, Matej Bel University in Banská Bystrica. Faculty of Economics.

Wansink, Brian, and Jeffery Sobal. 2007. "Mindless Eating: The 200 Daily Food Decisions We Overlook." Environment and Behaviour 39(1): 106123. https://doi.org/10.1177/0013916506295573.

WHO. 2020. "WHO Coronavirus Disease (COVID-19) Dashboard.” Accessed June 30, 2021. https://covid19.who.int /?gclid= Cj0KCQiAk53 BRD0ARIsAJu NhpvieBzMzZ4DF9MV5yFy VTAK2aagzpxDI7vybD1PQqfwfL3DAm 7DTEaAmAPEAL w_wcB.

Whitten, Sarah. 2020. "Board games, yoga mats, and yeast: What people are buying as they heed coronavirus stay-at-home orders." Accessed June 30, 2021. https://www.cnbc.com /2020/03/23/ what-people-are-buying-during-the-coronavirusoutbreak-and-why.html.

Wojdynski, Bartosz W. 2016. "Native advertising: Engagement, deception, and implications for theory." In The New Advertising: Branding, Content and Consumer Relationships in a Data-Driven Social Media Era, edited by Ruth E. Brown, Valerie K. Jones, and Ming Wang, 203-236. Santa Barbara, CA: Praeger/ABC Clio.

Yuen Kum Fai, Xueqin Wang, Fei Ma, and Kevin X. Li. 2020. "The Psychological Causes of Panic Buying Following a Health Crisis." International Journal or Environmental Research and Public Health 17: 3513. https://doi.org/10.3390/ijerph17103513. 